\title{
THE INFLUENCE OF ISLAMIC CORPORATE GOVERNANCE AND INTERNAL CONTROL ON INDICATIONS OF FRAUD IN ISLAMIC COMMERCIAL BANKS IN INDONESIA
}

\author{
Uus Ahmad Husaeni $^{{ }^{*}}$, Reksa Jayengsari ${ }^{2}$, Selviana Zakiah $^{3}$ \\ *Corresponding Author \\ ${ }^{1}$ Islamic Economic Department, Faculty of Islamic Economic and Business, Universitas Suryakancana, Cianjur, West Java, \\ Indonesia, uusahmadhusaeni@unsur.ac.id \\ ${ }^{2}$ Islamic Banking Department, Faculty of Islamic Economic and Business, Universitas Suryakancana, Cianjur, West Java, \\ Indonesia, reksajayengsari@gmail.com \\ ${ }^{3}$ Master Program in Islamic Economics, Graduate School of State Islamic University of Sunan Gunung Djati, Bandung, West \\ Java, Indonesia, selvianazakiah@gmail.com
}

\begin{abstract}
This article aims to analyze ICG (Islamic Corporate Governance) and Internal Control on indications of fraud at Islamic Commercial Banks in Indonesia. The method used in this study is to use quantitative analysis with technical data analysis using multiple linear regression. The data used is secondary data obtained from Islamic banking financial reports, amounting to 60 data. The conclusion in this article is the influence of Islamic Corporate Governance which is proxied by the variables of the implementation of the Sharia Supervisory Board (abbreviated as DPS) duties and responsibilities, the performance of duties and responsibilities of the board of directors, and internal control, on the dependent variable, namely, the indication of fraud in Islamic Commercial Banks in Indonesia of 46.1 percent. In comparison, the rest, 53.9 percent, is influenced by other factors which are not used in this study.
\end{abstract}

Keywords: fraud, Islamic corporate governance, Islamic banking, management, internal control.

Received

March 18, 2021

To cite this article:
Revised

March 31, 2021
Accepted

July 30, 2021
Published

September 30, 2021

Husaeni, U. A., et al. (2021). The influence of Islamic corporate governance and internal control on indications of fraud in Islamic commercial banks in Indonesia. IJIBE (International Journal of Islamic Business Ethics), 6 (2), 92-103. http://dx.doi.org/10.30659/ijibe.6.2.92-103

\section{INTRODUCTION}

A bank is an entity that carries out activities to raise funds from the public in savings, financing, and credit and in other ways to improve the standard of living of the people at large. The development of the banking sector in Indonesia is interesting to observe, especially about the banking industry's ups and downs in Indonesia. There are two types of banks in Indonesia: banks that carry out their activities conventionally and banks that carry out their actions based on sharia principles or Islamic banks (Husaeni, 2017).

According to Law of the Republic of Indonesia Number 21 of 2008 concerning Islamic banking, Islamic banking is everything that concerns Islamic banks and Sharia Business Units, including institutions, business activities, and methods and processes for conducting their business activities. Islamic banks are banks that run businesses based on sharia principles or Islamic legal principles as regulated in the fatwas of the Indonesian Ulema Council, such as the principles of justice and balance ('adl wa tawazun), benefit (mashahah), universalism (alamyah), and do not contain gharar, maysir, usury, wrongdoers, and haram objects. Islamic banks consist of Sharia Commercial Banks (BUS), Sharia Business Units 
(UUS), and Sharia Rural Banks (BPRS). One of the Islamic banking principles is applying profit-sharing following the directions of Islamic teachings (Husaeni, 2017).

Along with Islamic banks' development, the greater the challenges that Islamic banks must face. Even though Islamic banks carry out their duties based on sharia principles, this does not guarantee that Islamic banks are free from fraud. In Indonesia, there have been many cases of fraud in sharia institutions. As is the case with the Bogor branch of Bank Syariah Mandiri regarding fictitious disbursements involving internal bank parties, amounting to 102 billion rupiahs to 197 fictional customers. The losses resulting from this incident amounted to 59 billion rupiahs, and the National Police-Criminal Investigation Unit named four suspects, three of which were BSM employees (Suhendi, 2013). In addition to these cases, several cases occurred, such as the case experienced by BRI Syariah and Bank Mega Syariah, which felt they were disadvantaged due to the gold pawning at BRI Syariah and Bank Mega Syariah (Sadikin, 2014).

In other countries, there are also many cases of Islamic banks, such as the case that happened to the Dubai Islamic Bank, which lost around the US \$ 300 billion due to incorrect financial reports, and the Islamic Bank of South Africa, which went bankrupt in 1997 with debts between R50 to R70 million caused by bad management as well as improper accounting and management systems (Rini, 2014). This case proves that Islamic institutions and sharia-based banks do not guarantee that they are free from fraud. Every organization has the risk of fraud in all its forms and modes.

Bank Indonesia Circular Letter No. 13/28 / DPNP states that fraud is an act of irregularity or deliberate omission to deceive, deceive, or manipulate a Bank, customer, or another party, which occurs within the bank and uses bank facilities resulting in the bank, customer, or other parties suffer losses or the fraudsters get financial benefits, either directly or indirectly. Fraud in an organization can be done by various levels, from management to owner (Anugerah, 2014). Ravaan et al. (2016) explained that there were 3 (three) conditions caused fraud or what is called the fraud triangle. First, there is a motive or pressure (incentive/pressure); secondly, there is an opportunity; third, there is a rationalization (attitude) and a tendency to justify his actions. For this reason, an entity with a unique character, the sharia financial business, has a high risk in its management, so the principle of the prudence of the perpetrators is needed in the aspect of sharia compliance to prevent the possible risk of fraud.

Sanusi, Rameli, and Isa (2015) stated that to meet compliance, Islamic banks recommend the Islamic Disclosure Index (IDI) developed based on three indicators of Islamic disclosure, namely sharia compliance, corporate governance, and social / environment disclosure. The concept of Good Corporate Governance (GCG) is an effort to improve systems, processes, and regulations in the management of an organization, which essentially regulates and clarifies the relationships, powers, rights, and obligations of all stakeholders. Good Corporate Governance (GCG) is intended to control stakeholders' relationships and prevent irregularities in implementing company strategy.

Islamic banks' operation is inseparable from the demands of the implementation of Good Corporate Governance and is based on sharia principles known as Islamic Corporate Governance. Asrori (2014) defines Islamic Corporate Governance (ICG) as follows: "Islamic corporate governance (ICG) seeks to devise ways in which economic agents, the legal 
system, and corporate governance a be directed by moral and social values based on shari'ah Laws. Its supporters believe that all economic, corporate, and business activities financially be based on an etha religious paradigm, with the sole aim of the religious welfare of individuals and society. In many ways, ICG pursues the same objectives as conventional corporate governance but within the religious-based moral codes of Islam. Islam's model of ICG may be proposed ceiling the purposes of Shari'ah laws with the stakeholder model of corporate governance".

Implementing corporate governance based on Islamic principles indicates that Islamic institutions, especially banks, are protected from fraudulent practices. Self-Assessment of Good Corporate Governance is a form of commitment to Good Corporate Governance, which is carried out periodically and refers to the parameters issued by Bank Indonesia. Self Assessment is used as a paradigm to measure or assess the health of Islamic banking. There are 11 indicators or components of the assessment of Good Corporate Governance on Self Assessment.

These indicators are the implementation of duties and responsibilities of the board of commissioners, implementation of duties and responsibilities of the board of directors, completeness and performance of committee duties, implementation of duties and responsibilities of the sharia supervisory board, collection and distribution of funds, and services, handling of conflicts of interest, implementation of the compliance function. Banks, the internal audit function's performance, the implementation of the external audit function, the maximum limit of fund distribution, and transparency of financial and non-financial conditions, GCG implementation reports, and internal reporting.

Based on these GCG indicators, there are two Islamic Corporate Governance indicators used in this study, namely the implementation of the duties and responsibilities of the Sharia Supervisory Board (DPS) and the implementation of the duties and responsibilities of the Board of Directors / Directors. The Sharia Supervisory Board is an affiliated party to ensure Sharia principles' performance in Islamic banking activities (Faozan, 2013). SSB's task and authority are to periodically supervise Islamic financial institutions under its supervision (Yaya et al., 2013). The Sharia Supervisory Board is also in charge of providing advice and suggestions to the Board of Directors. The Board of Directors in Islamic banking is fully responsible for implementing BUS management based on prudential and sharia principles (Sula et al., 2014).

Implementation of SSB duties and responsibilities and the duties and responsibilities of directors are used as variables in this study because these two indicators have been used as variables in previous studies. Research conducted by Asrori (2014) uses DPS duties and responsibilities to indicate Islamic corporate governance. Furthermore, Ponduri and Begum (2014) also use DPS characteristics to display Islamic Corporate Governance. Maradita (2012) stated that the Sharia Supervisory Board is a supporting element for implementing GCG principles in Islamic banks. Based on this research, the performance of DPS duties and responsibilities and the execution of the directors' duties and responsibilities are critical indicators to ensure the implementation of sharia principles and avoid indications of fraud in Islamic banking.

In addition to implementing corporate governance based on Islamic principles, one crucial factor that companies must have and apply to reduce fraud is adequate internal 
control. Weak internal control can also incentivize individuals or groups to commit fraud (Thoyibatun et al., 2015).

Internal control, also called an integrated framework, is standard companies use to design, analyze, and evaluate internal control (Thoyibatun, 2012). The management of an entity is responsible for enforcing and maintaining internal control (Yuwannita and Ariani, 2016). The tendency of fraud is related to the internal control system in an organization, where reasonable internal control causes an organization to avoid fraud.

This research was conducted concerning studies conducted by Asrori (2014), Anugerah (2014), and Manurung et al. (2015). The difference between this study and research conducted by Asrori (2014) lies in the dependent variable. The performance of Islamic banks is the dependent variable, and Islamic Corporate Governance is the independent variable. In contrast, in this study, the dependent variable used is fraud. The difference between this study and research conducted by Anugerah (2014) is in the population used where Anugerah (2014) examines the role of Good Corporate Governance in preventing fraud in conventional institutions examines the effect of Islamic Corporate Governance on a copy in Islamic banks. Furthermore, the difference between this study and research conducted by Manurung et al. (2015) is located in the independent variable and the moderating variable, where Manurung et al. (2015) used organizational commitment as an independent variable on employee fraud as the dependent variable with internal control as the moderating variable, whereas in this study internal control was used as an independent variable to see its effect on indications of fraud. The difference also lies in the indicators or measuring instruments used to measure internal control. Research conducted by Manurung et al. (2015) Internal control is calculated using a questionnaire, whereas, in this study, the indicator or measuring instrument used to measure internal control is the composite value of the self-assessment results reported in the report on the implementation of Good Corporate Governance (GCG) for Islamic commercial banks.

\section{METHOD}

This study examines the effect of the independent variables, namely the implementation of the Sharia supervisory board's duties and responsibilities, the delegation of directors' duties and responsibilities, and internal control on the dependent variable, namely the indication of fraud through hypothesis testing.

This research is a type of causality research. Causality research explains the effect of independent variables on the dependent variable or describes the causal relationship between variables (Sekaran and Bogie, 2013). Researchers used a non-controlled situation in conducting this research, namely, without interfering with the company's routine activities. The unit of analysis used is the organizational level, namely Islamic Commercial Banks in Indonesia 2016-2020.

The population in this study is a Sharia Commercial Bank (BUS). The sample is a part of the community, a member of the people chosen to research. The sample selection was based on purposive sampling with the following criteria:

1. Sharia Commercial Bank (BUS) registered with Bank Indonesia consecutively for 2016, 2017, 2018, 2019, and 2020; 
2. Sharia Commercial Banks that publish reports on the implementation of Good Corporate Governance on each BUS's websites for the period 2016, 2017, 2018, 2019, and 2020;

3. Disclose data related to research variables and are entirely available.

The sample criteria used in this study can be seen in the following table:

Table 1: Determination of Research Samples

\begin{tabular}{|l|l|c|}
\hline No & \multicolumn{1}{|c|}{ Sample Criteria } & $\begin{array}{c}\text { Number } \\
\text { of Islamic } \\
\text { Bank }\end{array}$ \\
\hline 1 & $\begin{array}{l}\text { BUS registered with Bank } \\
\text { Indonesia for the 2016-2020 } \\
\text { period }\end{array}$ & 14 \\
\hline 2 & $\begin{array}{l}\text { BUS for which GCG report data } \\
\text { is available in full }\end{array}$ & 12 \\
\hline 3 & $\begin{array}{l}\text { BUS which reports GCG data } \\
\text { not completely available }\end{array}$ & $(2)$ \\
\hline \multicolumn{2}{|c|}{ Number of samples per period } & 12 \\
\hline \multicolumn{2}{|c|}{ Research period } & 60 \\
\hline \multicolumn{2}{|c|}{ Final sample number } & 5 \\
\hline
\end{tabular}

Source: Data processed (2020)

Data sources consist of primary data (referring to first-hand information) and secondary data (data that already exist and do not have to be collected by researchers). The data used in this research is secondary data. Data collection techniques are an integral part of the research design. Meanwhile, the data analysis technique used multiple regression analysis.

\section{RESULT}

\section{Description of Research Object}

This study aims to examine the influence of the Islamic corporate governance variable, which is proxied by the implementation of DPS duties and responsibilities, the performance of the duties and responsibilities of the board of directors, and the internal control variables on indications of fraud in Islamic commercial banks in Indonesia in 2016-2020. In this study, the research object was selected by the purposive sampling method using predetermined criteria.

Based on data obtained from each BUS's website, there is 14 BUS registered with Bank Indonesia for the 2016-2020 period. Based on the research sample in Table 1, the illustrations in this study were 12 banks. The data panel used is balanced data, where each observation period has the same number of companies. The number of samples in this study is 60 observations for the 2016-2020 observation period.

\section{Hypothesis test \\ Multiple Linear Regression Method}


This research is a research with hypothesis testing using multiple linear analysis methods to determine the effect of independent variables, namely the implementation of DPS duties and responsibilities, the performance of duties and responsibilities of the board of directors, and internal control dependent variable, namely fraud. The results of multiple linear regression can be seen in Table 2:

Table 2: Multiple Linear Regression Results

\begin{tabular}{|l|l|}
\hline Variable & $\mathrm{B}$ \\
\hline (Constant) & $-9,018$ \\
\hline $\begin{array}{l}\text { Implementation of duties and } \\
\text { responsibilities } \\
\text { DPS }\end{array}$ & 0,357 \\
\hline $\begin{array}{l}\text { Implementation of duties and } \\
\text { responsibilities of the board of directors }\end{array}$ & 0,484 \\
\hline Internal control & $-0,334$ \\
\hline
\end{tabular}

Source: Data processed (2021)

Based on Table 2, it can be obtained a new multiple linear regression equation, namely:

$\mathrm{Y}=-9,018+0,357 \mathrm{X} 1+0,484 \mathrm{X} 2-0,334 \mathrm{X} 3+\mathrm{e}$ Based on the multi linear regressive equation, it can be seen that:

1) Constant (a) of $-9,018$ indicates that if the implementation of DPS duties and responsibilities, the performance of duties and responsibilities of the board of directors, and internal control are mutually constant or do not experience change or zero, then the amount of fraud will decrease by - 9,018;

2) The regression coefficient for implementing DPS duties and responsibilities is 0.357 ; the positive regression coefficient value indicates a unidirectional relationship between the DPS duty and responsibility implementation variables and the fraud variable. This shows that for each increase in the DPS implementation of duties and responsibilities variable by 1 unit, there is an increase in fraud by 0.357 companies, assuming the other independent variables are constant;

3) The regression coefficient of the implementation of the duties and responsibilities of the board of directors is 0.484 . The positive regression coefficient value shows a unidirectional relationship between the variable performance of duties and responsibilities and the variable fraud. This indicates that for each increase in the implementation of the duties and responsibilities of the board of directors variable by 1 unit, there is an increase in fraud by 0.484 companies, assuming the other independent variables are constant;

4) The internal control regression coefficient is -0.334 ; the negative regression coefficient value indicates no direct relationship between the internal control and the fraud variables. This shows that every 1 unit increase in the internal control variable decreases fraud by -0.334 units, assuming the other independent variables are constant. 


\section{Coefficient of Determination (R2)}

Measurement of the coefficient of determination is carried out to determine the strength of the independent variable's influence on changes in the dependent variable. Determining the power of the research model can be seen from the R2 value, as shown in Table 3.

Table 3: Results of the Coefficient of Determination

\begin{tabular}{|l|l|l|l|l|l|}
\hline \multicolumn{5}{|c|}{ Model Summary } \\
\hline Model & R & $\begin{array}{l}\text { R } \\
\text { Square }\end{array}$ & $\begin{array}{l}\text { Adjusted } \\
\text { R Square }\end{array}$ & $\begin{array}{l}\text { Std. Error of } \\
\text { the Estimate }\end{array}$ & $\begin{array}{l}\text { Durbin } \\
\text { Watson }\end{array}$ \\
\hline 1 &, $547^{\text {a }}$ &, 461 &, 447 & 2,01242 & 1,796 \\
\hline a. Predictors: (Constant), VarX3, VarX2, VarX1 \\
\hline \multicolumn{2}{|l}{ b. Dependent Variable: VarY } \\
\hline
\end{tabular}

Source: Data processed (2020)

Based on Table 3, it can be seen that the $\mathrm{R} 2$ value is 0.461 or $46.1 \%$. This shows that $46.1 \%$ of the dependent variable or fraud can be explained by the three independent variables: the implementation of DPS duties and responsibilities, the implementation of duties and responsibilities of the board of directors, and internal control. In comparison, the remaining $53.9 \%$ is explained by other independent variables not included in this research.

\section{Simultaneous Significance Test (Test Statistic F)}

The simultaneous significance test shows whether all the independent variables included in the model have a joint influence on the dependent variable. The results of the $\mathrm{F}$ statistical test can be seen in Table 4.

Table 4: Result of F Test

\begin{tabular}{|c|c|c|c|c|c|}
\hline Model & $\begin{array}{l}\text { Sum of } \\
\text { Squares }\end{array}$ & Df & $\begin{array}{l}\text { Mean } \\
\text { Square }\end{array}$ & $\mathrm{F}$ & Sig. \\
\hline 1 Regression & 872,786 & 3 & 401,929 & 98,476 & 0,000 \\
\hline Residual & 322,925 & 57 & 4,051 & & \\
\hline Total & 1045,711 & 60 & & & \\
\hline
\end{tabular}

Source: Data processed (2020)

Based on Table 4, it can be seen that the significance value is 0.000 and is smaller than the 0.05 significance level. It can be concluded that the independent variables, namely, the implementation of DPS duties and responsibilities, the performance of duties and responsibilities of the board of directors, and internal control together affect. The dependent variable, namely, fraud.

\section{Individual Significance (t Statistical Test)}


The $\mathrm{t}$ statistical test shows how far the influence of one independent variable individually in explaining the dependent variable [19]. The results of the t statistical test can be seen in Table 5 .

Table 5: Statistical Test Results t

\begin{tabular}{|c|c|c|c|c|c|c|}
\hline & \multirow{2}{*}{ Model } & \multicolumn{2}{|c|}{$\begin{array}{l}\text { Unstandardize } \\
\text { d Coefficients }\end{array}$} & \multirow{2}{*}{$\begin{array}{l}\text { Standardize } \\
\text { d } \\
\text { Coefficients }\end{array}$} & \multirow{2}{*}{$\mathrm{T}$} & \multirow{2}{*}{ Sig. } \\
\hline & & B & $\begin{array}{l}\text { Std. } \\
\text { Error }\end{array}$ & & & \\
\hline \multirow[t]{4}{*}{1} & (Constant & $-9,018$ & 3,548 & & $-2,254$ & 0,013 \\
\hline & VarX1 & 0,357 & 0,054 & 0,457 & 6,567 & 0,000 \\
\hline & VarX2 & 0,484 & 0,066 & 0,512 & 7,361 & 0,000 \\
\hline & VarX3 & $-0,334$ & 0,049 & 0,432 & 6,294 & 0,000 \\
\hline
\end{tabular}

Source: Data processed (2020)

Based on Table 5, it can be seen that:

1. The test results on the DPS implementation of duties and responsibilities variable obtained the $t$ value of 6.567 . The significance value is less than 0.05 , namely 0.000 , which means that the Islamic Corporate Governance variable with the proxy for implementing DPS duties and responsibilities affects the indication of fraud at Islamic Commercial Banks in Indonesia in 2016-2020. This shows that the first hypothesis, which states that the implementation of DPS 'duties and responsibilities affects copy, is accepted;

2. The test results on the variable of the performance of duties and responsibilities of the board of directors obtained the $t$ value of 7.361. The significance value is more significant than 0.05 , namely 0.000 , which means that the Islamic Corporate Governance variable with the proxies for implementing the duties and responsibilities of the board of directors affects the indication of fraud in Islamic Commercial Banks in Indonesia in 2016-2020. This shows that the second hypothesis, which states that the implementation of the duties and responsibilities of directors affects fraud, is accepted;

3. The test results on the internal control variable obtained the t value of 6.294. The significance value is more significant than 0.05 , namely 0.000 , which means that the internal control variable affects the indication of fraud at Islamic Commercial Banks in Indonesia in 2016-2020. This shows that the third hypothesis, which states that internal control affects copy, is accepted.

\section{DISCUSSIONS}

Based on the results of multiple linear regressions that have been obtained in this study, the following will discuss the effect of the independent variable, namely Islamic Corporate 
Governance with the proxies for the implementation of DPS duties and responsibilities, the performance of duties and responsibilities of the board of directors and the internal control variable on the dependent variable, namely fraud.

\section{Effect of DPS Implementation and Responsibility, Implementation of Duties and Responsibilities of the Board of Directors, and Joint Internal Control on Indications of Fraud}

Based on the results of statistical tests, the Islamic Corporate Governance variable, together with the proxies for the implementation of DPS duties and responsibilities, the performance of the duties and responsibilities of the board of directors, and the internal control variables, have an effect on the indication of fraud in Islamic Commercial Banks in Indonesia for the 2016-2020 period.

This is because the study results indicate that partially testing all independent variables affects the dependent variable. The independent variables also affect the dependent variable jointly. Some of the factors that may cause are the robust internal corporate governance mechanism (Anugerah, 2014), the implementation of Islamic corporate governance, and the substantial internal control caused by the company's internal audit (Agoes, 2013).

\section{The Effect of DPS Implementation of Duties and Responsibilities on Indications of Fraud}

Implementing SSB's duties and responsibilities is one indicator of corporate governance performance based on Islamic principles (Islamic Corporate Governance). The Sharia Supervisory Board is tasked with overseeing Islamic banks' activities to comply with sharia principles. Based on the results of statistical tests, partially, the implementation of DPS duties and responsibilities affects indications of fraud at Islamic Commercial Banks in Indonesia for the 2016-2020 period.

Based on the existing theory, the application of Islamic corporate governance is significant and indicates to the public that Islamic banking is protected from fraudulent practices. Management of Islamic banks based on Islamic principles will run well with the supervision of DPS. The results of this study indicate that the implementation of DPS's duties and responsibilities affects fraud estimated because, in its performance, it can apply corporate governance with Islamic principles to the fullest. The existence of DPS guarantees that Islamic banking will avoid indications of fraud (Mollah \& Zaman, 2015). Robust internal corporate governance mechanisms are also one of the causes of fraud prevention (Anugrah, 2014). The main strengths of Islamic banking's internal corporate governance mechanism are mainly related to SSB competence and the fulfillment of sharia compliance in its operational activities (Asrori, 2014).

This study's results are different from the research of Najib and Rini (2016), which states that Islamic Corporate Governance has no effect on fraud in Islamic banks in Indonesia. A study conducted by Mollah and Zaman (2015) says that SSC has no impact on Islamic bank performance if only acts as an advisor. This study's results are consistent with the results of research conducted by Anugerah (2014), which states that good corporate governance can reduce the level of fraud. Asrori's (2014) study also says that implementing DPS duties and responsibilities positively affects Islamic banks' Islamic performance. 


\section{The Effect of Implementation of Duties and Responsibilities of the Board of Directors on Indications of Fraud}

The implementation of duties and responsibilities of the board of directors is one indicator of Islamic corporate governance. Based on the results of statistical tests, partially, the performance of the board of directors' duties and responsibilities affects the indication of fraud at Islamic Commercial Banks in Indonesia for the 2016-2020 period.

The theory states that the board of directors is obliged to manage BUS following their authority and responsibility and implement ICG in every BUS business activity. The Board of Directors is fully responsible for implementing the management of Islamic Commercial Banks based on prudential principles and sharia principles. This study indicates that the implementation of duties and responsibilities of directors does not affect fraud. This is thought to be due to the difficulty of implementing corporate governance based on Islamic principles. Islamic banks in Indonesia are still relatively new and are still in the adjustment and development stage, so it cannot be said that they have fully implemented Islamic principles. This makes it difficult for the board of directors to carry out their duties and responsibilities in managing the BUS. Fraud in the organization can be done by various levels, from management to owner (Anugrah, 2014). Implementing the duties and responsibilities of the board of directors will not guarantee that Islamic banking is protected from fraud indications because fraud in companies can take various forms, such as management fraud and white-collar crime (fraud committed by the upper class) (Agoes, 2013).

This study's results are different from the research conducted by Najib and Rini (2016), which stated that Islamic corporate governance does not affect fraud. This study's results are consistent with the research results conducted by Anugerah (2014), which says that GCG can reduce the level of fraud. Research conducted by Mollah and Zaman (2015) states that board structure and CEO power hurt Islamic banking performance.

\section{Effect of Internal Control on Indications of Fraud Occurrence}

Internal control is a standard that companies use to evaluate activities within the company. Based on statistical testing results, partially internal control has no effect on indications of fraud in Islamic Commercial Banks in Indonesia for the 2016-2020 period. This is estimated because, based on the calculation of high internal audit ranking data, the level of internal fraud in Islamic banks is still high. Internal control, as measured by the proxy for implementing internal audit, affects copy. One of the causes of fraud is a weakness in internal control caused by a company's malfunction of the internal audit department (Agoes, 2013). The role of internal auditors is enormous in preventing fraud in Islamic banks. Internal audit's function is to provide assurance services for companies for operational efficiency and internal control (Anugrah, 2014).

This study's results are consistent with Spatacean's (2012) research, which states that increasing the effectiveness of internal controls will reduce the risk of fraud. Thoyibatun's (2012) research also says that the internal control system's suitability affects unethical behavior. The study conducted by Manurung et al. (2016) stated that organizational commitment harms employee fraud with the effectiveness of internal control system control as a moderating variable. 


\section{CONCLUSION}

Based on the discussion of the research results that have been stated previously, it can be concluded that: a) Islamic Corporate Governance with the proxies for the implementation of DPS duties and responsibilities, the performance of the duties and responsibilities of the board of directors, and internal control together affect indications of fraud in Islamic Commercial Banks in Indonesia for the period 2016-2020; b) The implementation of DPS duties and responsibilities impacts signs of fraud in Islamic Commercial Banks in Indonesia for the 2016-2020 period; c) The performance of the duties and responsibilities of the board of directors affects indications of fraud in Islamic Commercial Banks in Indonesia for the 2016-2020 period; d) Internal control impacts signs of fraud in Islamic Commercial Banks in Indonesia for the period 2016-2020.

\section{REFERENCES}

Agoes, S. (2013). Auditing: Petunjuk Praktis Pemeriksaan Akuntan oleh. Akuntan Publik. Jakarta: Salemba Empat.

Anugerah, R. (2014). Peranan Good Corporate Governance dalam Pencegahan Fraud. Jurnal Akuntansi Fakultas Ekonomi Universitas Riau. 3(1): 101-113.

Asrori. (2014). Implementasi Islamic Corporate Governance dan Implikasinya Terhadap Kinerja Bank Syariah. Jurnal Dinamika Akuntansi. 6(1): 90-102.

Baz, R., Shamsiah, R., Ayoib B. Che-Ahmad., \& Popoola, O. M. G. (2016). Capability Component of Fraud and Fraud Prevention in the Saudi Arabian Banking Sector. International Journal of Economies and Financial Issues. 6(4): 68-71.

Foazan, A. (2013). Implementasi Good Corporate Governance dan Peran Dewan Pengawas Syariah di Bank Syariah. La Riba: Jurnal Ekonomi Islam. 7(1).

Husaeni, U. A. (2017). Determinan Pembiayaan pada Bank Perkreditan Rakyat Syariah di Indonesia. Esensi: Jurnal Bisnis dan Manajemen. 7(1), 49-62.

Husaeni, U. A. (2017). Determinan Profitabilitas pada Bank Pembiayaan Rakyat Syariah di Indonesia. Ekspansi. 9(1), 155-163.

Manurung, D., Suhartadi, A. R. \& Saefuddin, N. (2015). The Influence of Organizational Commitment on Employee Fraud with Effectiveness of Internal Control and Organizational Juctice as a Moderating Variable. Procedia-Social and Behavioral Sciences. 211: 1064-1072.

Maradita, A. (2012). Karakteristik Good Corporate Governance Pada Bank Syariah dan Bank Konvensional. Yuridika. 12 (2).

Mollah, S., \& Zaman, M. (2015). Sharia Supervision, Corporate Governance and Performance: Conventional vs. Islamic banks. Journal of Banking \& Finance. 58: 418435.

Najib, H., \& Rini. (2016). Analisis Faktor Yang Mempengaruhi Fraud di Bank Syariah. Simposium Nasional Akuntansi XIX, Lampung. Otoritas Jasa Keuangan. Statistik Perbankan Syariah, Agustus 2016.

Ponduri., V. Sailaja \& Begum, S. A. (2014). Corporate Governance-Emerging Economies Fraud and Fraud Prevention. IOSR Journal of Business and Management. 16(3): 01-07.

Rini. (2014). The Effect of Audit Committee Role and Sharia Supervisiory Board Role on 
Financial Reporting Quality at Islamic Banks in Indonesia. Journal of Economics, Business, and Accountancy Ventura. 17(1): 145-156.

Sadikin, R. (2014). Bank Mega Syariah Terseret Kasus Gadai Emas Seret. https://www.tribunnews.com/bisnis/2014/05/10/bank-mega-syariah-terseret-kasusgadai-emas-seret. Diakses pada 31 Januari 2021.

Sanusi, Z. M., Rameli, M. N. F., \& Isa, Y. M. (2015). Fraud Schemes in The Banking Institusions: Prevention Measures to Avoid Severe Financial Loss. Procedia Economies and Finance. 28: 107-113.

Sekaran, U., \& Bogie, R. (2013). Research Methods for Business. Sixth Edition. Wiley.

Spatacean, I. O. (2012). Addressing Fraud Risk by Testing the Effectiveness of Internal Control over Financial Reporting-Case of Romanian Financial Investment Companies. Procedia Economies and Finance. 3: 230-235.

Suhendi, A. (2013). Modus Kredit Fiktif BSM Bogor Hampir Sempurna: Ini Peran Ketujuh $\begin{array}{lllll}\text { Tersangka } & \text { Pembobol } & \text { Rp } & 102 & \text { M. }\end{array}$ https://www.tribunnews.com/metropolitan/2013/11/08/modus-kredit-fiktif-bsm-bogorhampir-sempurna-ini-peran-ketujuh-tersangka-pembobol-rp-102-m. Diakses pada 31 Januari 2021.

Sula, A. E., Alim, M. N., \& Prasetyo. (2014). Pengawasan, strategi Anti Fraud dan Audit Kepatuhan Syariah sebagai Upaya Fraud Preventive pada Lembaga Keuangan Syariah. JAFFA. 2(2).

Thoyibatun, S., Sudarma, M., \& Sukoharsono, E. G. (2009). Analysing The Influence Of internal Control Compliance and Compensation System Against Unethical Behavior and Accounting Fraud Tendency (Studies at State University In East Java. Simposium Nasional Akuntansi 12, Palembang. Universitas Sriwijaya.

Thoyibatun, S. (2012). Faktor-Faktor yang Berpengaruh Terhadap Perilaku Tidak Etis dan Kecenderungan Akuntansi serta Akibatnya Terhadap Kinerja Organisasi. Ekuitas: Jurnal Ekonomi dan Keuangan. 16(2): 245-260.

Yaya, R., Martawireja, A. E. \& Abdurahim, A. (2013). Akuntansi Perbankan Syariah: Teori dan Praktik Kontemporer. Jakarta: Salemba Empat.

Yuwannita, A., \& Ariani, N. E. (2016). Analisis Hubungan Pengendalian Internal Versi Coso Terhadap Indikasi Kecurangan Laporan Keuangan Pada Baitul Qiradh Anggota Pusat Koperasi Syariah Nanggroe Aceh Darussalam. Jurnal Ilmiah Mahasiswa Ekonomi Akuntansi. 1(1): 199-209. 